\title{
Larvicidal efficiency of the fungus Amanita muscaria (Agaricales, Amanitaceae) against Musca domestica (Diptera, Muscidae)
}

\author{
Luiz Paiva Carapeto \\ Marcial Corrêa Cárcamo * \\ Jucelio Peter Duarte \\ Luíze Garcia de Melo \\ Eduardo Bernardi \\ Paulo Bretanha Ribeiro \\ Universidade Federal de Pelotas, Campus Universitário Capão do Leão \\ CEP 96010-900, Pelotas - RS, Brasil \\ * Author for correspondence \\ marcial.carcamo@gmail.com
}

Submetido em 30/09/2016

Aceito para publicação em 10/07/2017

\section{Resumo}

Ação larvicida do fungo Amanita muscaria (Agaricales, Amanitaceae) em Musca domestica (Diptera, Muscidae). Foi relatada a ação larvicida de duas formulações de Amanita muscaria em Musca domestica. Dois métodos de extração foram testados: extrato aquoso de basidioma desidratado e triturado (BDT), e extrato de basidioma fresco liquefeito em água (BFL). A mortalidade causada pelo extrato BDT variou de $14,67 \%$ a $100 \%$. A eficácia do extrato BFL variou de 10,67 a 89,33\%. A concentração letal média $\left(\mathrm{CL}_{50}\right)$ do extrato BDT foi de, aproximadamente, $1.931,02$ ppm, enquanto que a $\mathrm{CL}_{50}$ do extrato BFL foi em torno de $30 \%$. As substâncias extraídas por esses métodos de extração não interferiram no período de desenvolvimento dos imaturos e não influenciaram no peso pupal dos indivíduos. Esses resultados mostram o potencial de extratos de $A$. muscaria para o controle de $M$. domestica.

Palavras-chave: Cogumelo; Extrato aquoso; Inseticida; Moscas; Vetor

\section{Abstract}

This work reports the larvicidal action of two formulations of Amanita muscaria against Musca domestica. Two methods of extraction were tested: an aqueous extract from dried, powdered basidiomes (DPB); and an extract from fresh basidiomes liquefied in water (FLB). The mortality caused by the DPB extract varied from $14.67 \%$ to $100 \%$. The efficiency of the FLB extract varied from $10.67 \%$ to $89.33 \%$. The mean lethal concentration $\left(\mathrm{LC}_{50}\right)$ of the DPB extract was approximately $1,931.02 \mathrm{ppm}$, whereas the $\mathrm{LC}_{50}$ for the FLB extract was about $30 \%$. The extracted substances from these methods did not interfere with the development period of immatures and did not influence pupal weight. These results show the potential of $A$. muscaria extracts for controlling $M$. domestica.

Key words: Aqueous extract; Flies; Insecticide; Mushroom; Vector 
Musca domestica Linnaeus, 1758 (Diptera, Muscidae) plays an important role in the health of humans and domestic animals because it can act as a mechanical vector of bacteria, viruses, fungi, protozoans, and helminths (FÖRSTER et al., 2007; MALIK et al., 2007; BARIN et al., 2010). In addition, this species can be a biological vector of Habronema muscae (Carter, 1861) (Spirurida, Habronematidae) and Habronema megastoma (Rudolphi, 1819) (Spirurida, Habronematidae), nematodes that cause gastric and cutaneous injuries in equids (JOHNSTON; BANCROFT, 1920).

Due to its vectorial ability and large populations, this species often needs to be controlled. Control is usually done with synthetic chemical insecticides, which cause many problems, such as environmental contamination, human and domestic animal poisoning, and the appearance of resistance in populations (ACEVEDO et al., 2009; KOZAKI et al., 2009; WANG et al., 2012).

As an alternative to synthetic insecticides, natural products have been studied (CABRAL et al., 2008). The most important ones are obtained from plants and, although poorly understood, some fungal species show insecticidal activity (MIER et al., 1996). Amanita muscaria (Linnaeus, 1758) (Agaricales, Amanitaceae) is popularly known as fly agaric because some traditional communities use solutions of this fungus to control flies (CORDIER, 1876; MOYEN, 1888 apud MIER et al., 1996). Insecticidal properties of Amanita muscaria are mainly associated with the action of ibotenic acid and muscimol (TAKEMOTO et al., 1964).

Although the use of this fungus by traditional communities is known (MICHELOT; MELENDEZ-HOWELL, 2003), there are no reports of its use against $M$. domestica immatures. Thus, this study aimed to evaluate the efficiency of aqueous extracts of $A$. muscaria against $M$. domestica immatures.

Adults of $M$. domestica were collected in Pelotas, Rio Grande do Sul, Brazil ( $\left.31^{\circ} 48^{\prime} \mathrm{S}, 52^{\circ} 25^{\prime} \mathrm{W}\right)$, identified with the help of a dichotomous key (CARVALHO et al., 2002), and maintained in cages $(30 \times 30 \times 30$ $\mathrm{cm})$. The $M$. domestica specimens were maintained according to Ribeiro et al. (2000) for rearing Ophyra aenescens (Diptera, Muscidae), differing only in the diet of the larvae, which in this work was composed of meat meal and sawdust (proportion 2:1). Throughout the experimental period, stock and test colonies were maintained in a climatic chamber $\left(25 \pm 2^{\circ} \mathrm{C}, \mathrm{RH} 70 \pm\right.$ 10\%, 12L: 12D).

Amanita muscaria specimens were collected in July in a grove of Pinus elliottii Engelmann, 1880 (Pinales, Pinaceae), in Capão do Leão, Brazil (31 $48^{\circ} 08.7^{\prime}$ 'S, $\left.52^{\circ} 24^{\prime} 51.2^{\prime \prime} \mathrm{W}\right)$. Basidiomes were collected with the pileus completely opened and were used to make two types of extracts: an extract from dried, powdered basidiomes (DPB); and an extract from fresh basidiomes liquefied in water (FLB).

For the first test (DPB extract), as soon as the basidiomes were collected they were placed in an incubator at $45^{\circ} \mathrm{C}$ for $96 \mathrm{~h}$, and then milled with an electric mill with $0.5 \mathrm{~mm}$ mesh. The crude extract was obtained from the fungal powder added to distilled sterile water in the proportion of $1: 10(\mathrm{w} / \mathrm{v})$. The resulting mixture was placed in a shaking incubator at $120 \mathrm{rpm}$ and $25^{\circ} \mathrm{C}$ for $48 \mathrm{~h}$. Then, the product was centrifuged for $10 \mathrm{~min}$ at 3,000 rpm and the supernatant was filtered using filter paper.

For this test, we prepared six concentrations: 0 ppm (control group), 928 ppm, 1,856 ppm, 2,784 ppm, 3,712 ppm and 4,640 ppm. We used 75 first-instar larvae divided in three replicates of 25 larvae for each concentration, totaling 450 individuals. Replicates were formed with $25 \mathrm{~g}$ of diet (composed of meat meal and sawdust in the proportion of 2:1) moistened with $25 \mathrm{~mL}$ of extract or distilled sterile water (control group). The container with the diet and larvae was placed in a larger container with moistened sawdust so the post-feeding larvae could abandon the substrate and pupariate in the sawdust. The larger container was closed with voile.

We observed the treatments daily and the postfeeding larvae found outside of the substrate were placed in containers with slightly moistened sawdust. We weighed the pupae after 48 hours and watched them until adult emergence. 
The second test (FLB extract) followed the same procedure as the first test, differing only in the solution that was used to moisten the diet that, in this test, was obtained from the liquefaction of fresh basidiomes in water.

We prepared six concentrations with the fresh basidiomes and distilled sterile water (w/v): $0 \%$ (control group), $10 \%, 20 \%, 30 \%, 40 \%$, and $50 \%$. The mixture was filtered with filter paper, the solid portion was discarded, and the liquid was used to moisten the diet where the larvae were placed.

For both tests, total mortality (larval and pupal), development period, and pupal weight were evaluated using an analysis of variance (ANOVA) and means compared by Tukey's test $(\mathrm{p}<0.05)$. $\mathrm{LC}_{50}$ and $\mathrm{LC}_{90}$ of each test were estimated with a Probit analysis. All analyses were performed using the software SPSS for Windows, version 22.0 (SPSS INC., 2013).

The DPB extract caused significant mortality of $M$. domestica immatures $(\mathrm{F}=185.07 ; \mathrm{DF}=5 ; \mathrm{p}<0.001)$.
The mean mortality varied from $44.00 \%$ to $100 \%$, whereas the control group showed a mean mortality of $10.67 \%$ (Table 1).

The FLB extract also caused significant mortality $(\mathrm{F}=178.87 ; \mathrm{DF}=5 ; \mathrm{p}<0.001)$. The mean mortality varied from $25.33 \%$ to $89.33 \%$, whereas the control group showed a mean mortality of about $6.67 \%$ (Table 1 ). For the first concentration of both extracts, we did not observe an insecticidal effect.

The mean lethal concentration $\left(\mathrm{LC}_{50}\right)$ of the DPB extract was $1,931.02 \mathrm{ppm}$ and the $\mathrm{LC}_{90}$ was $3,174.30$ ppm. For the FLB extract, the $\mathrm{LC}_{50}$ was $29.77 \%$ and the LC $_{90}$ was $49.42 \%$ (Table 2).

The development period (larva to adult) of $M$. domestica was not influenced by the DPB extract $(\mathrm{F}=3.73 ; \mathrm{DF}=3 ; \mathrm{p}=0.1)$ or the FLB extract $(\mathrm{F}=0.37$; $\mathrm{DF}=5 ; \mathrm{p}=0.86)$ of A. muscaria . The mean period varied from $14.50(928 \mathrm{ppm})$ to 14.98 days (control) for the DPB extract, and from 14.38 (40\%) to 14.85 days (20\%) for the FLB extract (Table 3).

TABLE 1: Mean mortality (\%) of Musca domestica subjected to different concentrations of Amanita muscaria aqueous extracts from dried, powdered basidiomes (DPB), and fresh basidiomes liquefied in water (FLB).

\begin{tabular}{cccc}
\hline \multicolumn{2}{c}{ DPB extract } & \multicolumn{2}{c}{ FLB extract } \\
\hline $\begin{array}{c}\text { Concentration } \\
(\mathbf{p p m})\end{array}$ & $\begin{array}{c}\text { Mean mortality } \\
(\mathbf{\%}) \pm \mathbf{S D} *\end{array}$ & $\begin{array}{c}\text { Concentration (mushroom: water) } \\
\mathbf{( w :} \mathbf{v})\end{array}$ & $\begin{array}{c}\text { Mean mortality } \\
(\mathbf{\%}) \pm \mathbf{S D} \text { * }\end{array}$ \\
\hline Control & $10.67 \pm 2.31 \mathrm{~A}$ & Control & $6.67 \pm 2.31 \mathrm{~A}$ \\
928 & $14.67 \pm 6.11 \mathrm{~A}$ & $10 \%$ & $10.67 \pm 8.33 \mathrm{~A}$ \\
1,856 & $44.00 \pm 4.00 \mathrm{~B}$ & $20 \%$ & $25.33 \pm 6.93 \mathrm{~B}$ \\
2,784 & $88.00 \pm 8.00 \mathrm{C}$ & $30 \%$ & $48.00 \pm 2.31 \mathrm{C}$ \\
3,712 & $93.33 \pm 6.11 \mathrm{C}$ & $40 \%$ & $78.67 \pm 6.11 \mathrm{D}$ \\
4,640 & $100 \mathrm{C}$ & $50 \%$ & $89.33 \pm 4.00 \mathrm{D}$ \\
\hline
\end{tabular}

* In the columns, values followed by different letters represent a significant difference between mean mortalities of each concentration (Tukey's test $-\mathrm{p}<0.05$ ).

TABLE 2: Lethal concentrations of Amanita muscaria aqueous extracts (from dried, powdered basidiomes - DPB, and fresh basidiomes liquefied in water - FLB) required to cause the death of $50 \%$ and $90 \%$ of Musca domestica immatures.

\begin{tabular}{ccccc}
\hline Extracts & $\mathbf{L C}_{\mathbf{5 0}}(\mathbf{C I})$ & $\mathbf{L C}_{\mathbf{9 0}}(\mathbf{C I})$ & Slope $\pm \mathbf{S E}$ & $\mathbf{X}^{\mathbf{2}}$ \\
\hline \multirow{2}{*}{ DPB } & $1,931.02$ & $3,174.30$ & $0.01 \pm 0.001$ & 15.12 \\
& $(1,751.62-2,098.03) \mathrm{ppm}$ & $(2,949.71-3,469.87) \mathrm{ppm}$ & & \\
\multirow{2}{*}{ FLB } & 29.77 & 49.42 & $0.06 \pm 0.006$ & 3.74 \\
\hline
\end{tabular}


TABLE 3: Development period (larva to adult) (days) and pupal weight (mg) of Musca domestica originating from larvae subjected to different concentrations of aqueous extracts of Amanita muscaria: from dried, powdered basidiomes (DPB), and from fresh basidiomes liquefied in water (FLB).

\begin{tabular}{cccccc}
\hline \multicolumn{3}{c}{ DPB extract } & \multicolumn{4}{c}{ FLB extract } \\
\hline $\begin{array}{c}\text { Concentrations } \\
(\mathbf{p p m})\end{array}$ & $\begin{array}{c}\text { Period } \\
\text { (larva to adult) } \\
\text { (days) } \pm \text { SD }\end{array}$ & $\begin{array}{c}\text { Pupal weight } \\
(\mathbf{m g}) \pm \text { SD }\end{array}$ & $\begin{array}{c}\text { Concentrations } \\
\text { (mushroom: water) (w: v) }\end{array}$ & $\begin{array}{c}\text { Period } \\
\text { (larva to adult) } \\
\text { (days) } \pm \text { SD }\end{array}$ & $\begin{array}{c}\text { Pupal weight } \\
(\mathbf{m g}) \pm \text { SD }\end{array}$ \\
\hline Control & $14.98 \pm 0.95$ & $27 \pm 2$ & Control & $14.42 \pm 1.15$ & $25 \pm 2$ \\
928 & $14.50 \pm 0.92$ & $25 \pm 1$ & $10 \%$ & $14.55 \pm 0.78$ & $27 \pm 1$ \\
1,856 & $14.57 \pm 0.77$ & $25 \pm 2$ & $20 \%$ & $14.85 \pm 0.69$ & $23 \pm 2$ \\
2,784 & $14.56 \pm 0.72$ & $24 \pm 2$ & $30 \%$ & $14.41 \pm 0.81$ & $25 \pm 3$ \\
3,712 & $*$ & $*$ & $40 \%$ & $14.38 \pm 0.50$ & $26 \pm 1$ \\
4,640 & $*$ & $*$ & $50 \%$ & $14.63 \pm 0.74$ & $*$ \\
\hline
\end{tabular}

* Groups that were not evaluated because they did not have the minimum number of individuals.

The substances of $A$. muscaria extracted using the methods did not influence the pupal weight of $M$. domestica: $\mathrm{DPB}$ extract $(\mathrm{F}=2.07 ; \mathrm{DF}=3 ; \mathrm{p}=0.12)$ and FLB extract $(\mathrm{F}=0.87 ; \mathrm{DF}=4 ; \mathrm{p}=0.08)$. The mean pupal weight varied from $24 \mathrm{mg}(2,784 \mathrm{ppm})$ to $27 \mathrm{mg}$ (control) for the DPB extract, and from $23 \mathrm{mg}(20 \%)$ to $27 \mathrm{mg}(10 \%)$ for the FLB extract (Table 3).

Our study shows, for the first time, that aqueous formulations of $A$. muscaria exhibit larvicidal activity against $M$. domestica. Due to resistance of this insect species to synthetic chemical insecticides, similar studies had already been described as important in the 1960s (PETZSCH, 1960); however, little was known beyond reports from traditional communities.

We observed that the larvicidal effect was dosedependent, as reported by Cárcamo et al. (2016) for Culex quinquefasciatus (Diptera, Culicidae) larvae subjected to the same fungal species. However, the efficiency that we observed was lower than observed by these authors. They reported an $\mathrm{LC}_{50}$ of about $50 \mathrm{ppm}$, and in the present study we estimated a concentration of $1,931 \mathrm{ppm}$ to kill the same percentage of larvae. These differences are probably associated with specific features of these species, since the method of extraction was the same for both experiments.

The larvicidal effect of $A$. muscaria was not observed by Mier et al. (1996) for Drosophila melanogaster (Diptera, Drosophilidae) larvae. For this fly, other Amanita species were considered toxic: A. phalloides, A. citrina and A. rubescens. Larvicidal action can be associated with different factors, such as the method used to obtain the active ingredient, since the way fungal compounds are extracted influences larvicidal activity (THONGWAT et al., 2015).

The two tested formulations killed immatures of $M$. domestica, and the FLB extract was easier to produce. Nevertheless, it can only be produced in colder seasons when fresh basidiomes of A. muscaria grow in Rio Grande do Sul, Brazil (BERNARDI, E.: personal communication, 2015). On the other hand, the DPB extract can be stored up to six months without losing efficiency (CÁRCAMO et al., 2016).

The inability of these two extracts to alter the development period and pupal weight is probably due to the mode of action of the toxic compounds. The main compound found in A. muscaria is muscimol (MICHELOT; MELENDEZ-HOWELL, 2003), which is a potent agonist of GABA (FRØLUND et al., 2002) that acts as a neurotoxic insecticide.

We obtained promising results with two methods of application of $A$. muscaria as a larvicidal insecticide. In addition, this is the first scientific report of the use of aqueous extracts as an insecticide against $M$. domestica larvae, which is an important species in urban and animal production environments. Nonetheless, other aspects of its use, such as the impact of this insecticide against 
non-target populations and its efficiency under field conditions, must be thoroughly evaluated.

\section{Acknowledgments}

The authors thank the Conselho Nacional de Desenvolvimento Científico e Tecnológico (CNPq) (MS and Ph.D. scholarships granted to the second author under Grant 141796/2010-3) and Fundação de Amparo à Pesquisa do Estado do Rio Grande do Sul (FAPERGS) (MS scholarships granted to the third author).

\section{References}

ACEVEDO, G. R.; ZAPATER, M.; TOLOZA, A. C. Insecticide resistance of house fly, Musca domestica (L.) from Argentina. Parasitology Research, Berlin, v. 105, n. 2, p. 489-493, 2009.

BARIN, A.; ARABKHAZZELI, F.; RAHBARI, S.; MADANI, S. A. The house fly, Musca domestica, as a possible mechanical vector of Newcastle disease virus in the laboratory and field. Medical and Veterinary Entomology, Oxford, v. 24, n. 1, p. 88-90, 2010.

CABRAL, M. M. O.; CRESCENTE, E. R. F.; MENDONÇA, P. M.; GOMES, C. M. S.; OLIVEIRA, V. C.; KELECOM, A. Melia azedarach L. extracts and their activity on Musca domestica L. (Diptera: Muscidae). Revista Brasileira de Farmacognosia, Curitiba, v. 18, p. 699-702, 2008.

CÁRCAMO, M. C.; CARAPETO, L. P.; DUARTE, J. P.; BERNARDI, E.; RIBEIRO, P. B. Larvicidal efficiency of the mushroom Amanita muscaria (Agaricales, Amanitaceae) against the mosquito Culex quinquefasciatus (Diptera, Culicidae). Revista da Sociedade Brasileira de Medicina Tropical, Uberaba, v. 49, n. 1, p. 95-98, 2016.

CARVAlHO, C. J. B.; MOURA, M. O.; RIBEIRO, P. B. Chave para adultos de dípteros (Muscidae, Faniidae, Anthomyiidae) associados ao ambiente humano no Brasil. Revista Brasileira de Entomologia, São Paulo, v. 46, n. 2, 2002.

FÖRSTER, M.; KLIMPEL, S.; MEHLHORN, H.; SIEVERT, K.; MESSLER, S.; PFEFFER, K. Pilot study on synanthropic flies (e. g. Musca, Sarcophaga, Calliphora, Fannia, Lucilia, Stomoxys) as vectors of pathogenic microorganisms. Parasitology Research, Berlin, v. 101, n. 1, p. 243-246, 2007.

FRØLUND, B.; EBERT, B.; KRISTIANSEN, U.; LILJEFORS, T.; KROGSGAARD-LARSEN, P. GABA-A receptor ligands and their therapeutic potentials. Current Topics in Medicinal Chemistry, Hilversum, v. 2, n. 8, p. 817-832, 2002.
JOHNSTON, T. H.; BANCROFT, M. J. The life-history of Habronema in relation to Musca domestica and native flies in Queensland. Proceedings of the Royal Society of Queensland, Brisbane, v. 32, n. 5, p. 61-88, 1920.

KOZAKI, T.; BRADY, S. G.; SCOTT, J. G. Frequencies and evolution of organophosphate insensitive acetylcholinesterase alleles in laboratory and field populations of the house fly, Musca domestica L. Pesticide Biochemistry and Physiology, San Diego, v. 95, n. 1, p. 6-11, 2009.

MALIK, A.; SINGH, N.; SATYA, S. House fly (Musca domestica): a review of control strategies for a challenging pest. Journal of Environmental Science and Health, Part B, New York, v. 42, n. 4, p. 453-469, 2007.

MICHELOT, D.; MELENDEZ-HOWELL, L. M. Amanita muscaria: chemistry, biology, toxicology, and ethnomycology. Mycology Research, Amsterdam, v. 107, n. 2, p. 131-146, 2003.

MIER, N.; CANETE, S.; KLAEBE, A.; CHAVANT, L.; FOURNIE, D. Insecticidal properties of mushroom and toadstool carpophores. Phytochemistry, New York, v. 41, n. 5, p. 1293-1299, 1996.

PETZSCH, H. Zur Toxizität des Fliegenpilzes (Amanita muscaria L.) für Diptera insbesondere die Grosse Stubenfliege (Musca domestica L.). Beiträge zur Entomologie, Berlin, v. 10, n. 3-4, p. 405-409, 1960

RIBEIRO, P. B.; CARVALHO, C. J. B.; CHERNAKI, A. M.; COSTA, P. R. P. Longevidade, oviposição e viabilidade pupal de Ophyra aenescens Wiedemann, 1830 (Diptera, Muscidae, Azeliinae), em condições de laboratório. Revista Brasileira de Agrociência, Pelotas, v. 6, n. 3, p. 264-268, 2000.

SPSS INC. SPSS 22.0 for Windows. Chicago: Illinois, 2013.

TAKEMOTO T.; YOKOBE, T.; NAKAJIMA, T. Studies on the constituents of indigenous fungi. II. Isolation of the flycidal constituent from Amanita strobiliformis. Yakugaku Zasshi, Tokyo, v. 84, p. 1186-1188, 1964.

THONGWAT, D.; PIMOLSRI, U.; SOMBOON, P. Screening for mosquito larvicidal activity of thai mushroom extracts with special reference to Steccheriunim sp. against Aedes aegypti (L.) (Diptera: Culicidae). Southeast Asian Journal of Tropical Medicine and Public Health, Bangkok, v. 46, n. 4, p. 586-595, 2015.

WANG, Q.; LI, M.; PAN, J.; DI, M.; LIU, Q.; MENG, F.; SCOTT, J. G.; QIU, X. Diversity and frequencies of genetic mutations involved in insecticide resistance in field populations of the house fly (Musca domestica L.) from China. Insect Molecular Biology, Oxford, v. 102, n. 2, p. 153-159, 2012. 